\title{
SALAMON Melinda
}

\section{A TQM ALKALMAZHATÓSÁGA A KÖZSZFÉRÁBAN}

A szerzố a teljes körú minôségmenedzsment közszervezetekben való adaptálhatóságát vizsgálja tanulmányában. Az új közmenedzsment-reformok hatására a minôségmenedzsment is egyre nagyobb teret kap a kormányzati szektorban. A közszektor hagyományos múködési modellje, valamint a közszolgáltatások sajátosságai azonban továbbra is gátat szabnak a vállalati minôségmenedzsment megfeleló átvételének. A szerzố a TQM magánvállalati kutatási tapasztalatait, valamint a közszektor jellemzóit felhasználva mutatja be a közszférában is alkalmazható TQM-technikákat.

\section{Kulcsszavak: teljes körú minôségmenedzsment, TQM, minôség, közszektor}

A minőségmenedzsment közszektorban való alkalmazása, mint sok más modernizációs törekvés, az ipari szektorból eredeztethető. A közmenedzsmentnek mint alkalmazott tudománynak legfóbb célja, hogy a társadalompolitikai célok megvalósítását a versenyszférában használt eszközök segítségével érje el (Horváth, 2005). Liu (2002) a közmenedzsmenten a kormányzati tevékenységek irányítását, menedzselését érti, aminek egyik megvalósítási módja a vállalati megközelítések adaptálása. A magánvállalati menedzsmentmódszerek adaptálhatósága azonban hosszú idő óta vita tárgyát képezi. Ez alól a minőség kérdése és a teljes körú minőségmenedzsment (TQM) sem kivétel.

A minőség komplex fogalom, pontos definíciója nem adható meg. Juran számára a használatra való alkalmasság jelentette a minőséget, Fiegenbaum szerint a minôség a szervezet irányításának egy módja, míg Crosby „,az igényeknek való megfelelést és nem az eleganciát" értette rajta (Tenner - DeToro, 2005; Morgan - Murgatroyd, 1991). A minőségi jellemzók elemzésére Garvin (1987) nyolc minőségdimenziót határozott meg, melyek a vevốk elvárásainak megértéséhez nyújtanak segítséget a szervezetek számára: teljesítmény, különleges tulajdonságok, megbízhatóság, megfelelés, tartósság, szervizlehetőségek, esztétika, minőség észlelése.

Vörös (2002) bevezette a minőséginfláció fogalmát, ami a vásárlók azon elvárásából ered, hogy a termékek teljesítményében folyamatos javulást várnak. Ebból ki- folyólag a minőség szinten tartása nem elegendő a piaci részesedés fenntartásához. A szerző analitikus modellje segítségével megállapította azt is, hogy ugyanannak a teljesítménynek (piaci részesedés vagy profitnagyság) az eléréséhez mind a minôség, mind a múködési kiválóság javítására képesnek kell lennie a szervezetnek. A szerző egy másik cikkében (Vörös, 2008) arra a következtetésre jutott, hogy az egyes termékek iránti kereslet nemcsak az ártól, hanem a minőségtôl is függ. A termelési költségek alakulását a termelékenység és a minőségi tudás befolyásolja. A minőség viszont piacon megvásárolható, azaz nem stratégiai tényezók alkalmazásával javítható.

\section{A teljes körü minőségmenedzsment}

A teljes körú minôségmenedzsment mint menedzsmentrendszer Deming azon elképzeléséból alakult ki, hogy a minőség egyrészt a felsố vezetés cselekedeteinek, döntéseinek következménye, másrészt a munkafolyamatok stabilitásáért a munkások felelősek. Ha így sem megfelelő a termékek minősége, akkor teljes szervezeti átalakításra van szükség. Deming minőséggel kapcsolatos filozófiáját 14 pontban fogalmazta meg. Vörös (2003) megfogalmazásában a TQM „olyan vállalatvezetési filozófia, amely a vezetés, a terméktervezés, a termelésirányítás, a tökéletesitési erófeszítések hajtóerejévé a minóséget teszi”. A modell három alapvetô elvre épül: a belsô és külsô vevốk 
középpontba állítására, a folyamatok folyamatos javítására, valamint az alkalmazottak bevonására (Tenner - DeToro, 2005). A teljes körú minőségmenedzsment további elemei a benchmarking, a termék- és szolgáltatástervezés, a folyamattervezés, a beszerzés, illetve a döntéstámogató eszközök (Krajewski et al., 2010; Vörös, 1999). Cua és szerzótársai (2001) kilenc TQM-gyakorlatot azonosítottak: folyamatmenedzsment, szervezeti egységeken átívelő terméktervezés, beszerzôii minőségmenedzsment, vevő́k bevonása, információ-visszacsatolás, elkötelezett vezetés, stratégiai tervezés, átfogó képzések és a dolgozók bevonása. Ezek közül is kiemelték a vezetôii elkötelezettség és a jól megalapozott stratégiai terv meglétének fontosságát.

A vállalati TQM, illetve a minôségmenedzsment témája mind elméleti, mind gyakorlati szempontból igen jól körbejárt terület a szakirodalomban. Hendricks és Singhal (1997) a TQM-programok hatékonyságának elemzésével arra az eredményre jutott, hogy a vizsgált, minőségi díjat nyert vállalatok esetén a múködési eredmény növekszik a TQM bevezetésének hatására, illetve magasabb árbevétel-növekedést érnek el a kontrollcsoporthoz viszonyítva. Vagyis empirikus kutatásaikkal sikerült bebizonyítaniuk, hogy a teljes körú minóségmenedzsment mint innovációs technika bevezetése hatékonyabb szervezeti múködéshez vezet. További empirikus kutatások is alátámasztották, hogy a teljes körú minőségmenedzsmentet választó szervezetek jobban teljesítenek, mint a TQM-et nem alkalmazó vállalatok. Yeung és szerzôtársai (2006) azt is kijelentik, hogy a TQM bevezetése alapvetô változásokkal jár, és még azok a szervezetek is költséghatékonyabbá válnak ennek hatására, amelyek csak felületesen alkalmazzák. Katona (2004) a TQM és a versenyképesség közötti kapcsolatot vizsgálta, és arra jutott, hogy a minőség mindenképpen befolyásolja azt. A TQM alkalmazásának hatása azonban csak hosszú távon jelenik meg, illetve mutatható ki.

Seetharaman és szerzőtársai (2006) kutatásaikban arra összpontosítottak, hogy mely tényezók szükségesek a minőségmenedzsment eredményességéhez. A TQM bevezetésének legfontosabb sikertényezójeként a vezetối elkötelezettséget és a minőség jelentôségének megértését határozták meg, ami magába foglalja az eróforrások biztosítását, az átlátható vezetést, és a változások támogatását. További sikertényezóként jelölték meg a TQM-filozófia és annak mérési technikáinak, módszereinek megértését, megvalósítási terv kidolgozását, a folyamatos javítás szükségességének elfogadását, valamint a vevók fontosságának megértését. Németh (2001) a magyar vállalatok körében vizsgálta a Total Quality Management bevezetésének sikertényezőit. Kutatásának eredményei azt mutatták, hogy Magyarországon az infrastrukturális háttér és a vállalati kultúra is kritikus faktor. Ha ezek kedvezóek, akkor a külföldi példákhoz hasonló eredmények születnek hazai környezetben.

Érdemes megjegyezni, hogy a just-in-time (,éppen idóben", JIT) termelési filozófia és a TQM között jelentôs átfedések mutatkoznak (Flynn et al., 1995). A just-in-time elsôdleges célja, hogy folyamatosan csökkentse, és végül kiküszöböljön mindenfajta veszteséget. A JIT úgy is definiálható, mint egy teljes körú termelési rendszer, amely arra irányul, hogy kreatív gondolkodással és ösztönzók alkalmazásán keresztül elérje a minőség javulását, a termelési folyamatok folyamatos javítását és a költségek kontrollját (Alles et al., 2000). Sakakibara és szerzôtársai (1997) empirikusan igazolták, hogy a just-in-time a termelési infrastruktúra javításán keresztuil közvetetten befolyásolja a vállalat teljesítményét. Kanonikus korrelációanalízis alkalmazásával tesztelték a JIT-technikák (átfutási idők csökkentése, megelőző karbantartás, üzemelrendezés, rugalmasság, Kanban, beszerzói kapcsolatok) együttese, illetve az infrastrukturális tevékenységek (minőségmenedzsment, emberierőforrás-menedzsment, termelési stratégia, terméktervezés, valamint más szervezeti sajátosságok) összessége és a termelési teljesítmény, továbbá a versenyelôny közötti összefüggéseket. Az infrastrukturális tevékenységek lényegében a just-intime termelést támogató funkciók. Ezek együttese a JIT-technikákkal kombinálva befolyásolja a vállalat teljesítményét.

A just-in-time TQM-mel közös elemei az elkötelezett vezetés, a stratégiai tervezés, a dolgozók bevonása, a képzések és a visszacsatolás. Az átfedések miatt egyes szerzók a JIT-t a TQM elemének tekintik (pl. Morgan - Murgatroyd, 1991), miközben inkább arról van szó, hogy együttes megvalósításuk elónyös. Empirikus kutatások is bizonyították, hogy a TQM és a JIT integrálása teljesítménynövekedéssel járó szinergiákat eredményez (Flynn et al., 1995; Cua et al., 2001). Napjainkban a just-in-time leginkább a karcsú (lean) menedzsment kapcsán kerül szóba, aminek egyik összetevőjeként tartják számon. A lean gondolkodás a Toyota termelési rendszeréból alakult ki és öt alapelv köré építkezik, melyek a következők: a vevői értékek meghatározása, az értékáram-elemzés, a folyamatos értékteremtés, a húzás elve és a tökéletességre való folytonos törekvés (Jenei, 2009). Losonczi és szerzőtársai (2010) vizsgálatai szerint a karcsúsítás az egész vállalati múködést átalakítja és pozitívan hat a versenyképességre is. 


\section{A közintézményi reformok hatása}

Ugyan maga a minőség fogalma ipari környezetben fogalmazódott meg először, de ma már a szolgáltatások és a közszolgáltatások esetén is értelmezik. A minőségmenedzsment fontossága a közszférában is egyre inkább elfogadottá válik, ami leginkább a '80-as években terjedt el, és még napjainkban is jelen lévő új közmenedzsment mozgalomnak köszönhető. Egyrészt a hetvenesnyolcvanas években kialakult recesszió következtében a fejlett országokban megnövekedett közkiadások és a közszolgáltatások nyújtásának magas kiadásai ráirányították a figyelmet a közszektor elégtelen hatékonyságára, valamint a bürokrácia túlburjánzására. Másrészt a piacgazdasági szolgáltatásnyújtásban bekövetkezett minőségjavulásnak köszönhetôen megnőtt az állampolgárok elégedetlensége a közszolgáltatásokkal szemben. Mindezek hatására több országban megkezdődött a közszektor reformja, modernizációja (Somogyi, 2006). A közintézményi menedzsmentreformok minden országban eltérô sajátosságokkal valósultak meg, de közös lényegi céljaik azonosíthatók (Jenei, 2005):

- javítani a közszféra hatékonyságát és eredményességét,

- erôsíteni a közszolgáltató intézmények felelôsségét az állampolgárok, a tulajdonképpeni szolgáltatásfogyasztók irányába,

- mérsékelni a közkiadásokat,

- fejleszteni a köztisztviselók elszámoltathatóságát.

Ezek a közszféra megújulására irányuló hasonló célok elérésére tett erófeszítések vezettek végül a menedzsmentmódszerek elterjedéséhez, és végsố soron az új közmenedzsment (New Public Management, NPM) reformmozgalom kialakulásához. A New Public Management „középpontjában olyan célkitúzések állnak, mint a közszektor hatékonyságának, eredményességének és fogyasztóorientációjának növelése, az állam leépítése, a privatizációra és az ún. piaci típusú mechanizmusokra való fokozott támaszkodás, illetve a kormányzás problémáinak újszerü, menedzsertípusú megközelitése és a magánvállalati menedzsmentben alkalmazott technikák és filozófia fokozott átvétele" (Hajnal, 2004).

\section{A közszektor sajátosságai}

A piaci szemlélet közszektorba integrálásával, valamint az ügyfél-orientáció követelményének megjelenésével a közintézmények számára a TQM alkalmazhatóságának kérdése is felvetődött. Azonban az új közmenedzs- ment-mozgalom által kiváltott, a privát szektor és a közszektor közötti közeledés ellenére is fennmaradtak olyan jellemzók, amelyek a közszervezetek tevékenységét megkülönböztetik a nyereségorientált vállalatokétól. A legfontosabb nehézségeket több szerző is (Alford, 2002; Dinya et al., 2004) összefoglalja.

A közszolgáltatók legkritikusabb és legtöbbet taglalt problémája, hogy nehéz megállapítani ki is az igazi „vevő”. Valójában már az elnevezésben sincs egyetértés: előfordul az ügyfél, a fogyasztó, a felhasználó, az érdekelt, az állampolgár, az adófizetô, a szavazó, vagy akár összességében a köz, mint e szervezetek célcsoportja. Koci (2005) az állampolgárok kilenc klaszterét sorolja fel: az állampolgár, aki egy közösség tagja (pl. adófizetô), az állampolgár, aki közintézmények felhasználója (verseny nélküli, ingyenes használat), az állampolgár, aki közintézmények felhasználója, de köteles használni a szolgáltatást, az állampolgár, aki adminisztratív jogszabályoknak van alávetve (korlátozott mozgástérrel), az állampolgár, aki jóléti szolgáltatásokat vesz igénybe, az állampolgár, aki közszolgáltatásokat pénzért vesz igénybe, közberuházó, aki szakmai kapcsolatban áll a közszervezettel, szervezeti egységek, amelyek belsố szolgáltatást nyújtanak, munkatársak, akik belső vevók. Alford (2002) úgy különbözteti meg az állampolgárt a vevőtôl, hogy elóbbi közértéket, míg utóbbi magánértéket kap a fogyasztása során. A közértéket mindig közösen fogyasztják vagy élvezik, szemben a magánértékkel, ami egyéni felhasználást feltételez. Alford tovább bontja a vevốk csoportját, és kedvezményezettnek nevezi azokat, akik a fogyasztáskor nem fizetnek, vagyis nem gazdasági cserével jutnak a közszolgáltatáshoz. Ebben az esetben a szervezet nem törekedhet a szolgáltatásnyújtás maximalizálására, hanem egy racionális optimum a cél, amit pedig a különbözó vevôi igények összevetésével lehet meghatározni. A vevókkel kapcsolatban további érdekes jellemző, hogy a pozitív preferencia feltételezése a közszolgáltatások esetén nem mindig áll fenn. Vannak esetek, amikor a „vevơ” az akarata ellenére kényszerül a szolgáltatás igénybevételére.

Ezen túlmenően a közszervezetek többsége számos csoportot vagy közönséget szolgál ki. A két legnagyobb csoport a szponzorok (állam, adófizetók) és az ügyfelek (akik a szolgáltatást igénybe veszik) csoportja. A közintézmények viszont nehezen tesznek különbséget az egyes csoportok között. A hivatalnokok úgy érzékelik, hogy az ügyfelek a velük kapcsolatban álló személyek, érdekcsoportok, vállalatok, vagy akár iparágak (például abban az esetben, ha azok felügyeletét látják el). Ezzel szemben a hivatalnokok az igazi ügyfelekkel csak nagyon ritkán találkoznak közvetlenül (pl. a rendôrök 
esetén sem a búnözốk az ügyfelek, hanem az állampolgárok, akiknek a biztonságát hivatottak szolgálni). A törvényeken, szabályozásokon keresztül azonban közvetetten rendelkezésükre áll az információ, hogy milyen közigények kielégítésére van szükség.

A küldetés és a fennálló igények kielégítése között ellentmondás jelentkezhet. A felmerülő igények ellentétben állhatnak a társadalom hosszú távú céljaival, érdekeivel, illetve az is elképzelhető, hogy a szuverén, egyedi igények nem állnak összhangban a társadalmi igényekkel. Azoknál a közintézményeknél, ahol lehetôség van bevételszerzô tevékenységet folytatni, a bevétel maximalizálásának elve szintén összeütközésbe kerülhet a szervezet küldetésével. Társadalmi viselkedésre is irányulhat a szervezet tevékenysége. Például a célközönség viselkedésének megváltoztatása szintén megjelenhet közcélként.

A siker mérése az ellentmondó célkitúzések következtében bizonytalanná válik. A közintézmények nem pénzügyi természetú célokat túznek ki, hajlamosak a túlköltekezésre, ami viszont a társadalmi haszonnal ellensúlyozódik. Mivel a jövedelmezóség optimuma nem értelmezhetó, nehéz az egyes alternatívák között választani. Sokszor nem világos, hogy hogyan is állapítható meg a szervezet sikeressége, és az eredmények nem biztos, hogy számszerúsíthetớk, összesíthetók.

Walsh (1991) kiemeli a piacon jelen lévố résztvevốk közötti viszony jelentốs eltérését a magánpiachoz képest. A magánszférában a cserében (elméletileg) egyenrangú felek vesznek részt, ez a közszférában nem jellemző. A szerző a kollektivitást is kihangsúlyozza a közszolgáltatásokban, ami lehetőséget ad a társadalmi beavatkozásra, a közösségi választásra, és a szükségletek kielégítésének egyenlőségét is megcélozza. A közintézmények számára az árazás általában irreleváns, mivel a közszolgáltatások nagy része ingyenesen elérhetô. Néhány szolgáltatás esetében a közfinanszírozás kiegészítésére használnak díjakat, vagy megállapítanak árat a kereslet kontrollálására. Az árazás ekkor sem gazdasági alapon történik, hanem leginkább politikai döntésen alapul.

\section{A közszolgáltatások jellemzối}

A közszolgáltatások sajátosságait szintén érdemes részletesen áttekinteni a TQM közszektorbeli alkalmazhatóságának vizsgálatához. A közszolgáltatás a közszféra által nyújtott valamennyi szolgáltatás, melyek a közüzemi szolgáltatások és az intézményi közszolgáltatások csoportjára oszthatóak. Pukli (2002) a közszolgáltatások jellemzőiként a következôket sorolja fel:
- a szolgáltatás igénybevétele során közösség vagy a közösség egy-egy csoportjának tagjai egyenlöséget élveznek,

- a szolgáltatás igénybevétele során az igénybe vevớk általában passzívak, nincs is szükség az aktív részvételükre, sem meghatározott megállapodásra,

- a fogyasztók nem versenyeznek a szolgáltatás megszerzéséért.

Koci (2005) a közszolgáltatásokat nem piaci, nem versenyző (monopolisztikus) szolgáltatásokként határozza meg, melyeknél a profitmotiváció teljesen hiányzik. Az ügyfelek nem tudnak választani a szolgáltatók között, míg az árakat jogszabályok rögzítik. Ezenfelül kiemeli, hogy a közszolgáltatások előállításakor a keresletet és a kínálatot széles társadalmi nézópontból kell szemlélni, csupán a kereslet alapján nem lehet megszabni az előállítandó mennyiséget. Butler és Collins (1994) a közszervezetek által előállított „termékeket” három csoportba sorolja: szolgáltatások, közjavak és kötelességek/tiltások/létesítmények. Értelmezésükben a szolgáltatások megegyeznek a korábban idézett szerzók definícióival, míg a kötelességek, tiltások, létesítmények csoportját magatartást befolyásoló szabályokként értelmezik. A közjavak esetén a klasszikus közgazdasági meghatározást használják, mely szerint e „termékek” oszthatatlanok, és senki sem zárható ki a fogyasztásukból, ezért potyautas magatartás jellemzi óket.

A szolgáltatások legfontosabb tulajdonságait a HIPI-elv fogalmazza meg, amit a közszolgáltatásokra is érvényesnek tekintünk (Dinya et al, 2004; Butler Collins, 1994; Farnham - Horton, 1996):

- h(eterogenity) - változékonyság: a szolgáltatás nyújtása változó, annak személyessége miatt. Hiszen a közszolgáltatás teljesítéséhez közalkalmazottak személyes közremúködésére van szükség. Ezáltal a szolgáltató teljesítménye időben és térben heterogén lehet. A közszolgáltatások esetén megjelenik az a probléma, hogy a szervezet küldetése, ami társadalmi igényeket tükröz, nem feltétlenül konzisztens az egyedi igényekkel. Ez a szolgáltatások érzékelt minőségét is komolyan befolyásolhatja, hiszen az ügyfél nem biztos, hogy az kapja, amit várt, vagy amit szeretne, hanem azt, ami társadalmilag hasznos.

- i(ntangibility) - nemfizikai természet: kézzelfogható termék nem cserél gazdát, a szolgáltatás megismeréséhez, megítéléséhez igénybe kell azt venni. A szolgáltatás teljesítményének megítélésekor így a vélemények, attitúdök, tapasztalatok dominálnak. A nem fizikai jelleg még inkább 
megjelenik a közszférában, hiszen minden esetben társadalmi célok érdekében ténykednek a szervezetek, de az érzékelt szolgáltatás színvonalára sokszor a szolgáltatás fizikai tartalma alapján következtetnek az ügyfelek.

- $\mathbf{p}$ (ershability) - nem tárolható jelleg: a szolgáltatás nem raktározható, ezért az igénybe nem vett szolgáltatás nem pótolható. Egyúttal a kapacitáshiány azonnal a szolgáltatás iránti teljes kereslet teljesíthetetlenségét vonja maga után. A nem tárolható jelleg kezelése a szolgáltatások esetén azt jelenti, hogy a kereslet váratlan ingadozásaihoz való alkalmazkodás nem lehetséges. A szervezet fizikai kapacitásai kihasználatlanok maradnak a keresleti mélypontok idején, annak merevségéból kifolyólag, míg a keresleti csúcsok lefedését nem képesek megoldani. Utóbbi esetben nagy a kockázata annak, hogy a potenciális igénybe vevoók más szolgáltatóhoz fordulnak. A közszolgáltatók viszont általában monopolpiacon ténykednek, ebből kifolyólag egyrészt a potenciális ügyfelek nem kereshetnek más szolgáltatót, kiszolgáltatottak lesznek az egyetlen szolgáltatónak, ami miatt ismét az érzékelt minőség csorbul. Másrészt a szolgáltatókat sem ösztönzi semmi a kapacitásproblémák megoldására, és sok esetben nem vesznek tudomást a probléma létezéséről. Az új közmenedzsment-reformok keretében egyes országokban a voucher-rendszerek bevezetésével igyekeztek ezt kiküszöbölni. Hajnal (2004) definíciója szerint „a voucherek részben vagy egészben állami finanszírozású szolgáltatások igénybevételére jogosító »jegyek«, amelyeket tulajdonosuk annál a szolgáltatónál »költ el«, amelynél kívánja”. Ezáltal a szolgáltatást igénybe vevớk fogyasztóként, a szolgáltatást nyújtók pedig versenyzó piaci szereplóként tevékenykednek, ami a piaci verseny hatékonyság-javító tulajdonságait érvényre juttatják.

- i(nseparability) - elválaszthatatlanság: a szolgáltatás teljesítésének ideje egybeesik annak felhasználásával. Az elválaszthatatlanság miatt a folyamatba épített, forgalmazást megelőző szokásos minőség-ellenőrzés a szolgáltatások esetén nem alkalmazható, és a méretgazdaságosság elérésére sincs így mód. A szolgáltatások mind a szolgáltató, mind az igénybe vevő részéról meglévő személyes jellege a legkockázatosabb tényezô a minőség szempontjából. A személyzet tájékozatlansága vagy udvariatlansága komoly problémákat okozhat ezen a téren.
A HIPI-elv mellett fontos kiemelni a szolgáltatások más tulajdonságait is. Ilyen a szolgáltatások folyamatjellege, ami abból ered, hogy a szolgáltatás nyújtásakor a szolgáltatás mint eredmény mellett a folyamatot is el kell ,adni”, ugyanis a szolgáltatásnyújtás folyamatát az ügyfél átéli. Mivel a folyamat minôsége határozza meg az igénybe vevő elégedettségét, ezért a folyamat tekinthető a szolgáltatás egy dimenziójának is. A szolgáltatások további jellemzóje, hogy a vevô aktívan részt vesz a tranzakciós folyamatban. Az igénybe vevố aktivitása következtében az ügyfél által rendelkezésre bocsátott információk, valamint az együttmúködési hajlandósága is befolyásolja a szolgáltatás (észlelt) minôségét.

\section{TQM a közintézmények gyakorlatában}

Mind a közszektor jellemzói, mind pedig a közszolgáltatások tulajdonságai nagyban befolyásolják a teljes körú minőségmenedzsment közintézményekben való adaptálhatóságát. Számos ellenvetés sorolható fel a TQM közszférabeli alkalmazásával szemben. Madsen (1995) a teljes körú minőségmenedzsment akadályaként három korlátozó tényezốt nevesített. Egyrészt a közintézmények tradicionális múködési modellje az, ami nem kedvez a minőségmenedzsment bevezetésének. A közszervezetek a rájuk bízott forrásokat szigorú szabályok betartása mellett használják fel, míg a közszolgáltatást igénybe vevớk panaszaikat nem az intézmények felé, hanem a politikusok felé kell, hogy továbbítsák a szabályozások megváltoztatása érdekében. Madsen az ügyfélorientált közszolgáltatást veszélyeztetô politikai eróket és érdekcsoportokat, valamint a közintézmények szervezeti kultúráját tekinti fó akadályozó erőnek. Maram (2008) véleménye szerint a TQM aláássa az egyenlőséget, és a képviselet, a közösségi beleszólás kritikai szerepét csökkenti. Morgan és Murgatroyd (1991) hasonló TQM-mel szembeni ellenvetésekkel találkozott:

- magának a TQM-nek a természete meggátolja annak közszektorban való alkalmazását,

- maga a közszektor az, ami kedvezótlen a TQMmódszerek alkalmazására,

- a közszektort jellemző szakértői, hivatalnoki csoportok munkakultúrája akadályozza a teljes körú minőségmenedzsment bevezetését,

- a vevő/ügyfél fogalma sokkal problémásabb, mint a magánszférában,

- a közszolgáltatások nyújtása sokkal bonyolultabb, mint az iparitermék-elóállítás.

A fenti gátló faktorok elemzése alapján az a következtetés vonható le, hogy a közszolgáltatások előállítását tekintve a minőségmenedzsment alkalmazása va- 
lóban problémás lehet, ezért a TQM egyes elemeinek változatlanul hagyása, míg más eszközeinek adaptálása javasolt. A közintézményi TQM fö komponensei, melyek nélkül a teljes körú minőségmenedzsment nem múködtethető, a következók:

- küldetés és stratégia, illetve az ezekból levezetett eredményközpontú tervek a szervezet valamenynyi munkatársára vonatkozóan elengedhetetlen,

- a TQM és a dolgozók felhatalmazása, bevonása csak akkor lesz hatékony, ha egyértelmú, mérhető célokat határoznak meg,

- a minőséggel kapcsolatos törekvéseket irányítani és koordinálni szükséges, ezért a szervezeti struktúrában helyet kell biztosítani a minôség támogatására,

- a folyamatos minőségjavítás érdekében felhatalmazott munkacsoportok kialakítása szintén fontos eleme a TQM-nek,

- az adatokon alapuló döntéshozatal hozzájárul a folyamatok és a vevőigények rendszerszintú megértéséhez,

- a vezetôi elkötelezettséggel és kommunikációval kell demonstrálni a minőségmenedzsment fontosságát és az adatokon alapuló döntéseket,

- a jutalmazási és elismerési rendszert hozzá kell igazítani a szervezet stratégiai céljainak megvalósulásához,

- az elsődleges érdekeltek igényeinek teljesítése kritikus, ezért tisztázni kell, hogy a számos „vevô”, közül ki tekinthetô a legfontosabbnak,

- a minôségteamek múködtetése és a folyamatos javítás érdekében az alkalmazottakat képezni kell.

Adaptálandó TQM-elemeknek tekintik a „nulla hibát", az ügyfél-elégedettséget, az önirányító munkacsoportokat, az éppen időben (just-in-time) irányítást, valamint a beszállítókkal való partnerséget. Például a közszolgáltatások esetén a just-in-time filozófián az értéket nem teremtő tevékenységek kiküszöbölését (Morgan - Murgatroyd, 1991), illetve a folyamatszemléletú gondolkodást (Radnor - Walley, 2008) érthetjük. A szerzók javaslata, hogy ezeket szervezetenként kell felülvizsgálni és átdolgozni.

Swiss (1992) szintén a közszféra egyedi sajátosságait figyelembe vevő módosított ,reform TQM” alkalmazását ösztönzi, melyben az alkalmazottak felhatalmazása és a folyamatos javítása az „ortodox TQM-ből” átvett elemek.

Madsen (1995) a problémák feloldására egy olyan átfogó modellt vázol fel, amelyben a minôségbiztosítás, mint politikai funkció és a minőség-ellenôrzés mint szervezeti feladat jelenik meg. A modellben horizontá- lisan a szolgáltatásnyújtás folyamata, vertikálisan pedig az eróforrások biztosítása áll. Eszerint a minôségi követelményeket ${ }^{1}$, célokat az állampolgárok által választott politikai képviselő́k határozzák meg (illetve döntenek arról, hogy mely állampolgári csoportokat részesítenek eloónyben), továbbá biztosítják a megvalósításhoz szükséges struktúrát és erőforrásokat, míg a politikai vezetốk hivatottak az előírások teljesülését ellenőrizni. A közszervezeteknek az előírásoknak megfelelően kell a közszolgáltatásokat létrehozniuk, miközben (politikai korlátok nélkül) az állampolgár-fogyasztók igényei szerint alakítják a közszolgáltatások minôség-attribútumait. Vagyis a közintézményi vezetők felelőssége a külsố minőség biztosítása, a belsố minőség szem előtt tartásával, ami az alkalmazottak képzésével, motiválásával érhetố el. A közszervezet dolgozói a TQM eszközök alkalmazásával javítják a közszolgáltatások minőségét.

A teljes körú minőségmenedzsment közszektorbeli alkalmazhatósága nem maradt pusztán elméleti kérdés, a kétségek és ellenérvek ellenére a gyakorlati megvalósítás igen elterjedt. Számos empirikus kutatás számol be a közintézményi TQM megvalósításának tapasztalatairól.

Kanji és Moura e Sá (2007) a portugál közintézmények esetén támasztotta alá azt a feltételezést, hogy a TQM implementálása és a szervezeti kiválóság között kapcsolat van. Kijelentik, hogy a TQM fó elemeinek és eszközeinek megvalósítása elengedhetetlenül szükséges a közszervezetek teljesítményének javításához. McNary (2008) ennél visszafogottabban fogalmaz. Eredményei szerint a minőségmenedzsment-projektek ugyan nem eredményeznek megtakarításokat, de jelentôs ügyfél- és dolgozói problémák megoldásával járnak, ami összességében eredményesebb folyamatokhoz vezet.

Demuzere és szerzôtársai (2008) a minôségmenedzsment-eszközök és a menedzseri autonómia kapcsolatát vizsgálták 124 flamand közszervezetnél. Legfontosabb megállapításuk az volt, hogy az autonóm közszervezetek vezetôi a minôségmenedzsment eszközeit elsôsorban az információs aszimmetria csökkentése és a célkitúzésekkel kapcsolatos problémák kiküszöbölése érdekében használják. Továbbá a minőségmenedzsment-technikák alkalmazása sokszor nem racionális szempontok alapján történik, hanem a normák és értékek vezérelte döntések szerint.

Madarász (2007) az Állami Foglalkoztatási Szolgálat minőségirányítási modelljének bevezetését mutatja be. A TQM-szemléletû Általános Értékelési Keretrendszert alkalmazó megközelítés implementálása partnerközpontú munkavégzést, minőség iránti elkö- 
telezettséget, nagyobb hatékonyságot eredményezett. Magyarországon a közigazgatási szervek gyakorlatában ez a minőségmenedzsment-rendszer tekinthetô a legismertebbnek.

A CAF-modell (Általános Értékelési Keretrendszer vagy Közös Értékelési Keretrendszer) egy szervezeti önértékelési eszköz, a minôségügyi rendszerek közigazgatásra specializált és egységesített formája, ami segítséget nyújt a múködési színvonal javítására azáltal, hogy a teljesítmény állandó ellenőrzésére és a fejlesztés lehetôségének keresésére ösztönzi a szervezetet (Szente, 2003).

Kovács (2009) a magyar közszektor 49 szervezetének CAF-alkalmazási tapasztalatát dolgozta fel, és összességében arra a következtetésre jutott, hogy a keretrendszer hatékonyan segíti a szervezetfejlesztési célok megvalósítását. A vizsgált szervezetek a szervezet múködésének áttekintésében, a múködéssel kapcsolatos erősségek és gyengeségek beazonosításában, valamint a munkatársak bevonásában ítélték pozitívan a modellt. A CAF alkalmazásának nehézségeként merült fel az eltérô területekról szóló információk összegyújtése, illetve a mérôszámok kialakítása. Felmerült, hogy más minőségmenedzsment-rendszerekkel (pl. ISO, EFQM) való együttes alkalmazása pozitív eredményekkel járhat.

\section{Összegzés}

A teljes körú minőségmenedzsment múködtetése a közszféra szervezeteinél nehézségekbe ütközik. Egyrészt a közszektor és a privátszektor különbözőségei, mint a vevốk meghatározásának nehézségei, a komplex célkitúzések, az árazás hiánya okoznak problémát. Másrészt a közszolgáltatások sajátosságai (pl. fogyasztás kollektivitása, monopolisztikus szolgáltatások, oszthatatlanság) teremtik meg a közintézményi minőségmenedzsment korlátait. Az akadályok ellenére a TQM adaptálhatósága elméleti modellekkel alátámasztható, sikerült azonosítani a TQM kulcselemeit és a módosításra ítélteket. Továbbá mind külföldi, mind hazai gyakorlati tapasztalatok is bizonyították a mindent átfogó minőségmenedzsment a közszektor szervezeteiben való használhatóságát.

\section{Lábjegyzet}

\footnotetext{
${ }^{1}$ Az Állampolgári Charták (Citizen's Charter) tekinthetők ezek legjobb példájának, amik olyan mutatószám-gyújtemények, amelyek az állampolgárok közszolgáltatásokkal szembeni minőségi elvárásait tartalmazzák, és betartásuk számonkérhető a közszervezeteken (Bovaird - Löffler, 2008).
}

\section{Felhasznált irodalom}

Alford, J. (2002): Defining the Client in the Public Sector: A Social-Exchange Perspective. Public Administration Review, 2002. május-június, Vol. 62, No. 3, p. 337346.

Alles, M. - Amershi, A. - Datar, S. - Sarkar, R. (2000): Information and Incentive Effects of Inventory in JIT Production. Management Science, Vol. 46, No. 12, 2000. december, p. 1528-1544.

Bovaird, T. - Löffler, E. (ed.) (2008): Public Management and Governance. Routledge, London

Butler, P. - Collins, N. (1995): Marketing Public Sector Services: Conceps and Characteristics. Journal of Marketing Management, 1995, 11, p. 83-96.

Cua, Kristy O. - McKone, K.E. - Schroeder, Roger G. (2001): Relationships between implementation of TQM, JIT and TPM and manufacturing performance. Journal of Operations Management, 19 (2001), p. 675-694.

Demuzere, S. - Verhoest, K. - Bouckaert, G. (2008): Quality management in public sector organizations: which factors do make a difference? EGPA Conference, Erasmus University, Rotterdam, 2008. szeptember 3-6.

Dinya L. - Farkas F. - Hetesi E. - Veres Z. (2004): Nonbusiness marketing és menedzsment. KJK-Kerszöv, Budapest

Farnham, D. - Horton, S. (1996): Managing the New Public Services. Macmillan, Houndmills

Flynn, B.B. - Sakakibara, S. - Schroeder, R.G. (1995): Relationship between JIT and TQM: Practices and Performance. Academy of Management Journal, 1995, Vol. 38, No. 5, p. 1325-1360.

Garvin, D.A. (1987): Competing on the eight dimensions of quality. Harvard Business Review, NovemberDecember

Hajnal Gy. (2004): Igazgatási kultúra és New Public Management reformok egy összehasonlító tanulmány tükrében. Ph.D. értekezés

Hendricks, K.B - Singhal, V.R. (1997): Does Implementating an Effective TQM Program Actually Improve Operating Performance? Empirical Evidence from Firms That Have Won Quality Awards. Management Science, Vol. 43, No. 9, szeptember

Jenei Gy. (2005): Közigazgatás-menedzsment. Századvég Kiadó, Budapest

Jenei I. (2009): A lean elvek alkalmazása az egészségügyi folyamatok fejlesztésében. 110. sz. Múhelytanulmány, Budapesti Corvinus Egyetem, Vállalatgazdaságtan Intézet, 2009. január

Kanji, G. - Moura e Sá, P. (2007): Performance Measurement and Business Excellence: The Reinforcing Link for the Public Sector. Total Quality Management, Vol. 18, Nos 1-2, p. 49-56.

Katona K. (2004): A minőség mint a TQM központi kategóriája és a versenyképesség. Vezetéstudomány, XXXV. évf. 2004. 6. szám 
Koci, M. (2005): Customer segmentation in the public sector: A better route to improve customer satisfaction and organizational performance? The case of social security services in Switzerland. EGPA-Conference, 2005. augusztus 31-szeptember 3, Berne

Kovács Á. (2009): Hazai CAF alkalmazói tapasztalatok 2009; Új Magyar Közigazgatás, 2009 (2. évf), 10-11. szám, 78-80. old.

Krajewski, L.J. - Ritzman, L.P. - Malhotra, M.K. (2010): Operations management: Processes and Supply Chains. 9th ed. Prentice Hall, Upper Saddle River

Liu, P. (2002): Can Public Managers Learn from Trends in Manufacturing Management? International Public Management Review, Volume 3, Isssue 2, 2002, p. 44-59.

Losonczi D. - Demeter K. - Jenei I. (2010): A karcsú (lean) menedzsment és a versenyképesség. Vezetéstudomány, XLI. évf, 2010. 3. szám

Madarász S. (2007): Minóségirányítási rendszer bevezetése az Állami Foglalkoztatási Szolgálatnál. Minőség és Megbízhatóság, 2007. (40. évf.) 4. sz. 206-212. old.

Madsen, O.N. (1995): Public enterprise and total quality management. Total Quality Management, Vol. 6, No. 2.

Maram, A. (2008): Reassessment of the application of TQM in the public sector. International Public Management Review, Volume 9, Issue 1.

McNary, L.D. (2008): Quality Management in the Public Sector: Applying Lean Concept to Customer Service in a Consolidated Government Office. Public Administration Quarterly

Morgan, C. - Murgatroyd, S. (1991): Total Quality Management in the Public Sector - An international perspective. Open University Press, Buckingham Philadelphia

Németh B. (2001): A Total Quality Management alkalmazása Magyarországon. Vezetéstudomány, XXXII. évf. 2001. 11. szám

Pukli P. (2002): A közszolgáltatások kutatásának információs háttere. In: A közszolgáltatások marketingje és menedzsmentje. JATE Press, Szeged

Radnor, Z. - Walley, P. (2008): Learning to Walk Before We Try to Run: Adapting Lean for the Public Sector. Public Money and Management, Febr, p. 13-20.
Sakakibara, S. - Flynn, B.B. - Schroeder, R.G. - Morris, W.T. (1997): The Impact of Just-in-Time Manufacturing and Its Infrastructure on Manufacturing Performance. Management Science, Vol. 43, No. 9, Sept, p. 12461257.

Seetharaman, A. - Sreenivasan, J. - Boon, L.P. (2006): Critical Success Factors of Total Quality Management. Quality and Quantity, (2006)40, p. 675-695.

Somogyi A. (2006): Reformérett közügyek. Vezetéstudomány XXXVII. évf. 2006. különszám

Szente Z. (2003): A CAF-modell alkalmazásának eddigi hazai tapasztalatai és a továbbfejlesztés lehetôségei. Magyar Közigazgatás, 53. évf. 10. szám, 585-600. old.

Swiss, J.E. (1992): Adapting Total Quality Management (TQM) to Government. Public Administration Review, Vol. 52, No. 4.

Tenner, A.R. - DeToro, I.J. (2005): Teljes körú minőségmenedzsment. Negyedik kiadás, Múszaki Könyvkiadó, Budapest

Vörös J. (1999): Termelés-szolgáltatási rendszerek vezetése. Janus Pannonius Egyetemi Kiadó, Pécs

Vörös J. (2002): Product balancing under conditions of quality inflation, cost pressures and growth strategies. European Journal of Operational Research, 141 (2002), p. 153-166.

Vörös J. (2003): A minőség figyelembevételének szükségessége az egyensúlyi állapot meghatározásában. Közgazdasági Szemle, L. évf., 2003. január, 6-21. old.

Vörös J. (2008): A kereslet hatása az árak, a minőség és a fejlesztési döntések dinamikájára. Közgazdasági Szemle, LV. évf. 2008. december, 1094-1115. old.

Walsh, K. (1991): Citizens and Consumers: Marketing and Public Sector Management. Public Money \& Management, Summer

Yeung, A.C.L. - Cheng, T.C.E. - Lai, K. (2006): An Operational and Istitutional Perspective on Total Quality Management. Production and Operations Management, Vol. 15, No. 1, Spring, p. 156-170.

Cikk beérkezett: 2010. 3. hó

Lektori vélemény alapján véglegesítve: 2010. 5. hó 